\title{
Shield Bugs of the genus Elasmucha - Model Insect Group for Parental Care Demonstration for Outdoor Scientific School Activities in Central and Northern Europe
}

\section{Lubomír Hanel and Jana Hanelová}

Envigogika 9 (1) - Reviewed Papers/ Recenzované články

Published/ Publikováno 30. 5. 2014

DOI: $10.14712 / 18023061.437$

\begin{abstract}
Direct observation of the environment and practical scientific enquiry outside the classroom are fundamental to an understanding of the nature of science as well as a source of inspiration and motivation. Thanks to the inclusion of excursions (field trips) during biology lessons students can directly participate in the process of science and improve their scientific reasoning skills. This paper presents parental care as an important life-history animal strategy. This phenomenon can be easily demonstrated by invertebrates, e.g. bugs (Insects, Heteroptera). The procedures described here offer step-by-step instructions on how bugs are used to guide students within research field-trip observation. Students can observe and investigate this interesting behaviour on selected bug species in natural conditions. These activities can increase student's involvement and interest in biology. Although the activity mentioned above is aimed at high school students, it is easy to adapt it to other age groups. Presented proposals of school research can be used in various European regions with the vegetation formed by birch trees (Betula sp.).
\end{abstract}

\section{Key Words:}

active learning, outdoor biology, scientific observations, bugs (Heteroptera), parental care

\section{Ploštice rodu Elasmucha jako modelová skupina k prezentaci rodičovské péče při přírodovědných školních exkurzích ve střední a severní Evropě.}

\section{Abstrakt}

Pozorování různých procesů a dějů přímo $v$ prírodních podmínkách jsou důležitá pro pochopení vědeckého bádání, stejně jako zdroj inspirace a motivace. Díky zahrnutí vycházek (exkurzí) do výuky biologie se studenti mohou prakticky seznamovat se zásadami př́rodovědných průzkumů a zlepšit své vědecké logické myšlení. Článek představuje rodičovskou péči jako důležitou životní strategii živočichů. Tento jev Ize snadno prezentovat na některých bezobratlých, např. na plošticích (Insecta, Heteroptera). V článku popsané názorné postupy slouží $k$ lepší orientaci studentů $v$ problematice a umožní jim provádět vědecká pozorování. Studenti tak mohou pozorovat a zkoumat tento zajímavý projev chování živočichů na vybraných druzích ploštic $v$ jejich přirozeném prostředí. Tyto badatelské aktivity mohou zvýšit aktivní zapojení studentů do výuky i jejich zájem o biologii. Přestože prezentovaný návod na pozorování je především určen studentům středních škol, je snadné ho přizpůsobit i jiným věkovým skupinám. Uvedená badatelská školní aktivita může být využita v různých evropských regionech s porosty, kde jsou zastoupeny břízy (Betula sp.).

\section{Klíčová slova:}

aktivní výuka, přírodovědné exkurze, vědecké pozorování, ploštice (Heteroptera), rodičovská péče 


\section{Introduction}

The outdoor biology and scientific observations were discussed by many authors from various points of view (e.g. Dale, 1967; Openshaw and Whittle, 1993; Rudman, 1994; Higgins, 1996; Tal, 2001; Ballantyne and Packer, 2002; Barker et al., 2002; Howarth and Slingsby, 2006; Byrd et al., 2007; Hamilton-Ekeke, 2007; Prokop et al., 2007; Tal and Morag, 2009; Beames and Ross, 2010; Martin, 2010; Sandell and Öhman, 2010, 2012; Hanel and Hanelová 2011). These studies provide many excellent examples of outdoor practices and their use in education. Learning biology in an outdoor environment has a positive cognitive and affective impact on students (Fägerstam and Blom, 2012).

Ahmad (2011) presents new categories under cognitive domain: remembering, understanding, applying, analysing, creating and evaluation. The general aims and objectives of teaching any school subject can be developed and understood in the light of its scope, importance and educational taxonomy. There are intrinsic and extrinsic justifications for teaching science and its various branches of biology. Intrinsic factors emphasize the value of science as an educational activity. It includes fundamental interests in the discipline and the initiation into empirical modes of investigations. Extrinsic factors emphesize on the utility of science for its own sake and for the good of society. Knowledge of biological facts and theories should be imparted based on the child's age, intellectual level and experience so that the child can and should memorize given knowledge and recall or recognize it when it is required.

\section{Concerning didactics}

By observing animals in their own natural environment students can obtain complex perceptions facilitating better memorisation than by only verbal communication, watching movies or looking at pictures in books. Outdoor activities generally can distinctly contribute to environmental and ecological education: fostering responsible environmental behavior, effecting long-term changes of students' attitudes toward conservation and nature, and providing basic ecological knowledge (Bogner, 1998). The most important aim is the development of a scientific attitude among students: a set of values characterized by open-mindnedness, curiosity, belief in cause and effect relationship, rationality and logical thinking, empiricism, scepticism, critical thinking, objectivity and precision, suspended judgment, and a planned procedure in solving problems.

Training in scientific methods develops the ability to solve problems by applying a scientific approach and methods. It attempts to foster among students the habit of applying of scientific methods skillfully, with enthusiasm and confidence to solve their day-to-day problems. Students of science should be able to adopt steps of scientific methods. Scientific observation is deceptively simple: phenomena happen. Phenomena are observed, and phenomena are recorded. How difficult can it be to observe scientifically? The English detective Sherlock Holmes astutely remarked in one of his stories "A Scandal in Bohemia, "seeing is not observing". To observe scientifically requires much more than sensory perception and using one's senses. Sensing - although highly tangible is only one aspect of observation (Eberbach and Crowley 2009). True scientific observation requires the coordination of disciplinary knowledge, theory, practice, and the habit of paying attention. Scientific observation is not a domain-general practice, but one that goes hand in hand with disciplinary knowledge, theory, and practice. When observations are disconnected from disciplinary contexts, knowledge and what and how observe, we see but we do not observe. Without sufficient understanding of the underlying theoretical concepts of entomology, and without awareness that entomologists have sophisticated observational habits, students fail to learn about the biology of bugs and authentic scientific inquiry. Although children are intent observers, teachers must help 
them to understand and negotiate the natural world to allow them to become scientific observers (Vosniadou et Brewer, 1992).

The role of the teacher in this matter may be replaced by a specialist (entomologist) or parent with science knowledge (Gleason and Schauble, 2000). This paper presents a subject for observation and its evaluation for teachers and students. According to the teacher's instructions students can independently or with their teacher observe the bug's maternal care (Elasmucha sp.) as a way of engaging in authentic scientific inquiry and developing attention, diligence, orderliness and also patience. The results of different observations need to be evaluated by using, for example, statistical methods. Students learn to process and evaluate their observations and at the same time experience the use of mathematics (statistics) in the course of scientific observation. They can practically realize the difference between "everyday observations", "intermediate" and true "scientific observations" (Eberbach and Crowley, 2009). Students may observe the things that interest scientists (e.g. insects), but the way students observe and the ways they use their observations to make inferences are not necessarily scientific.

Science education and developmental psychology literature suggest that everyday and scientific observers notice, filter, and reason about the natural world differently: when practised by expert observers, observation plays a key role throughout the inquiry process, whereas everyday observers tend to apply observation primarily in the service of data collection.

Biology education in primary and high schools focuses on ecological and ethological phenomena in the animal kingdom. Animal behaviour can be observed and investigated within field trips (excursions) using model animals suitable for visual demonstration of these specific phenomena. The presented observations are then classified with regard to Bloom's taxonomy (Furst, 1981), see the Results and discussion chapter.

\section{Concerning biology}

Matthew et al. (1997) summarized information about insects as teaching tools in primary and secondary schools. Various manifestations of parental behaviour in animals are interesting and attractive for teaching purposes. Wilson (1975) has pointed out that several environmental factors facilitate the evolution of parental care in animals: stable or structured environments, physically stressful environments, rich and ephemeral resources, and predation. Parental care, in general, is presumed to increase growth rates, quality, and/or survival of young. Odhiambo (1960) analyzed parental care in bugs and non-social insects, Tallamy (1999) noted the care of offspring among insects. Kaitala and Mappes (1992) summarized the evolution of parental care in insects. Three basic models of parental care can be recognized within animals: paternal (care by males), maternal (care by females) and biparental (joint care by male and female). Parental care of offspring is a subsocial behaviour occurring often within arthropods, including insects. Types of parental care in Heteroptera are highly diversified, ranging from hiding eggs inside plant tissues to guarding eggs and subsequently caring for the nymphs. Parental care was found within the order Heteroptera in 15 families. The phenomenon of maternal but also rare paternal care (e.g. water bugs of the family Belostomatidae, see Smith, 1997) is known among Heteroptera. The terrestrial family of shield bugs (Acanthosomatidae) are thought to be chiefly phytophagous and most species are associated with trees and shrubs. According to Kumar (1974) in his world revision recognizes 47 genera; now this number is 54 genera, with about 200 species, and is one of the least diversified families within group Pentatomoidea. This family of bugs is found throughout the world but is most common in tropical and subtropical areas.

Some species of this family are very suitable for demonstrating maternal care. Individual maternal care is currently known in eleven species from four acanthosomatid genera, Anaxandra, Elasmucha, Sastragala and Sinopla. It is interesting that species belonging to another genera (e.g. Elasmostethus) of this family do not care for their offspring. 
The genus Elasmucha may be the ideal model insect group for parental care demonstration. Three species of the genus Elasmucha (E. ferrugata, E. fieberi, E. grisea) occur in Europe, especially in central and northern regions. These species are commonly overlooked, even though they are relatively abundant, proving that looking beyond the surface of nature is richly rewarded.

All three mentioned species are remarkable concerning their maternal care. The most explored Eurasian species of the Parent Bug, Gefleckte Brutwanze in German, Elasmucha grisea, is presented in detail in this paper with respect to its behaviour and use in school biology education. This theme has been already successfully used in biology education of primary and high schools in the Czech Republic (Hanel and Hanelová, 2006, 2011). Jiskrová (2013) successfully verified the appropriateness of presenting the bugs' parental care in the genus Elasmucha (using fieldwork and observations in insectaria) on pupils in primary schools in Central Bohemia in her dissertation. The topic was attractive to pupils and caused great interest among them as none of them so far had observed this extraordinary phenomenon. Parental care presentations of the genus Elasmucha were also successfully used in several biology seminars of Czech teachers between 2010 and 2013 (authors' results).

The following key can be used for determination of all European species belonging to the genus Elasmucha (compiled by authors):

\begin{tabular}{|c|c|c|c|}
\hline $1 a$ & $\begin{array}{l}\text { Pronotum is markedly pointed with } \\
\text { noticeable dark tips }\end{array}$ & $\begin{array}{l}\text { Elasmucha ferrugata Body size: } 7-9 \mathrm{~mm} \text {. } \\
\text { Usual hosting plants: European } \\
\text { blueberry }\end{array}$ & Fig. 1 \\
\hline$b$ & Pronotum is not markedly pointed & $\rightarrow 2$ & \\
\hline $2 a$ & $\begin{array}{l}\text { Yellowish ventral part of the body without } \\
\text { small dark spots, yellow antennae, only } \\
\text { their end is dark }\end{array}$ & $\begin{array}{l}\text { Elasmucha grisea Body size: } 6-9 \mathrm{~mm} \text {. } \\
\text { Usual hosting plants: birch, alder }\end{array}$ & Fig. 2 \\
\hline$b$ & $\begin{array}{l}\text { Yellowish ventral part of the body with } \\
\text { many small dark spots, antennae are } \\
\text { brown or blackish in their full length }\end{array}$ & $\begin{array}{l}\text { Elasmucha fieberi Body size: 6-9 mm. } \\
\text { Usual hosting plants: birch }\end{array}$ & Fig. 3 \\
\hline
\end{tabular}

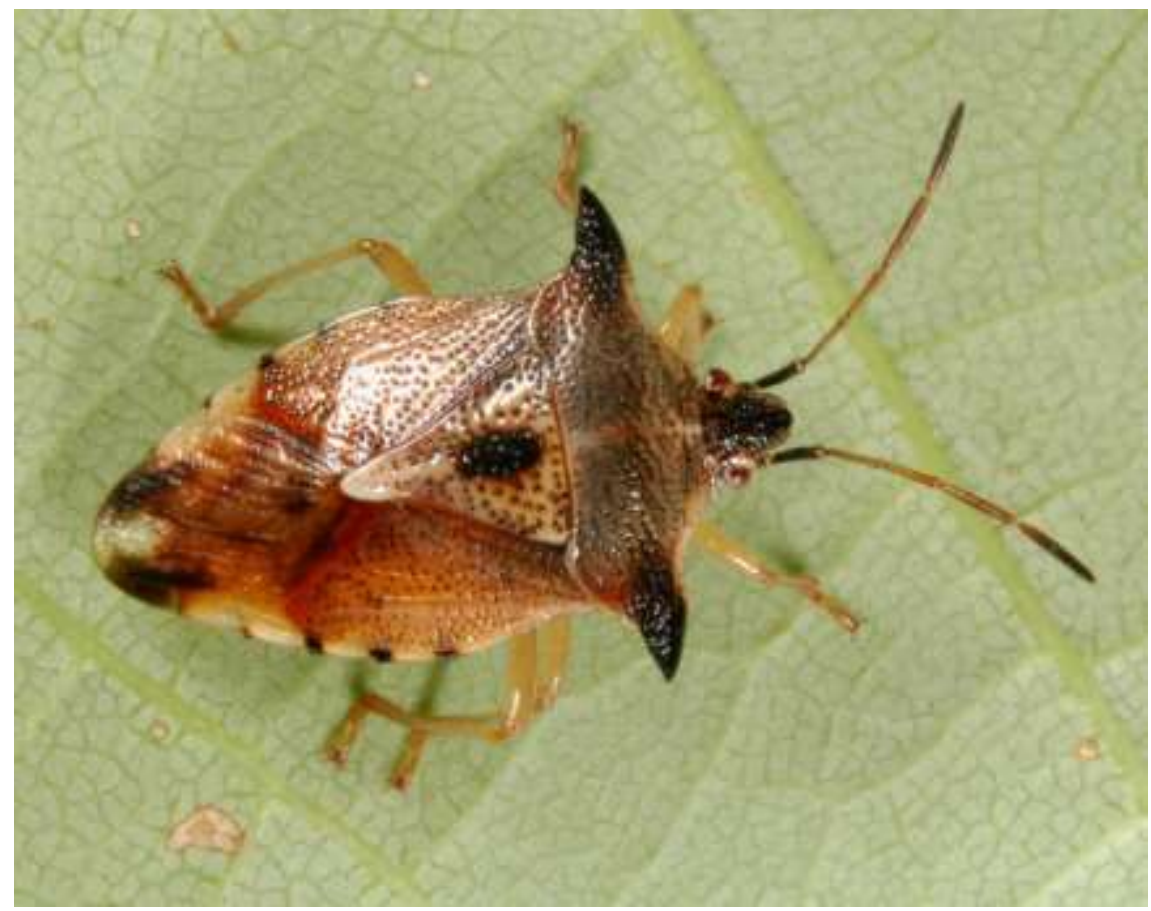

Fig.1: The Blueberry Shield Bug Elasmucha ferrugata. Central Bohemia. 


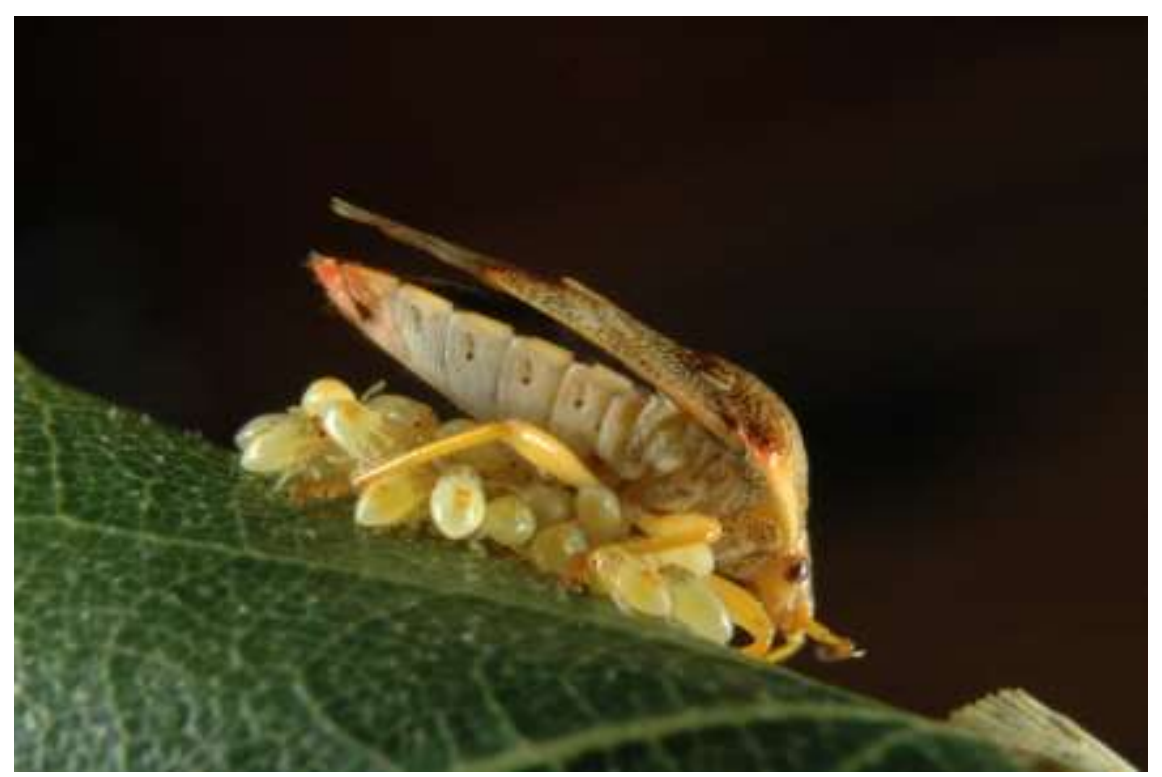

Fig. 2: The Parent Bug Elasmucha grisea. The female guarding nymphs ( $1^{\text {st }}$ instar). Central Bohemia.

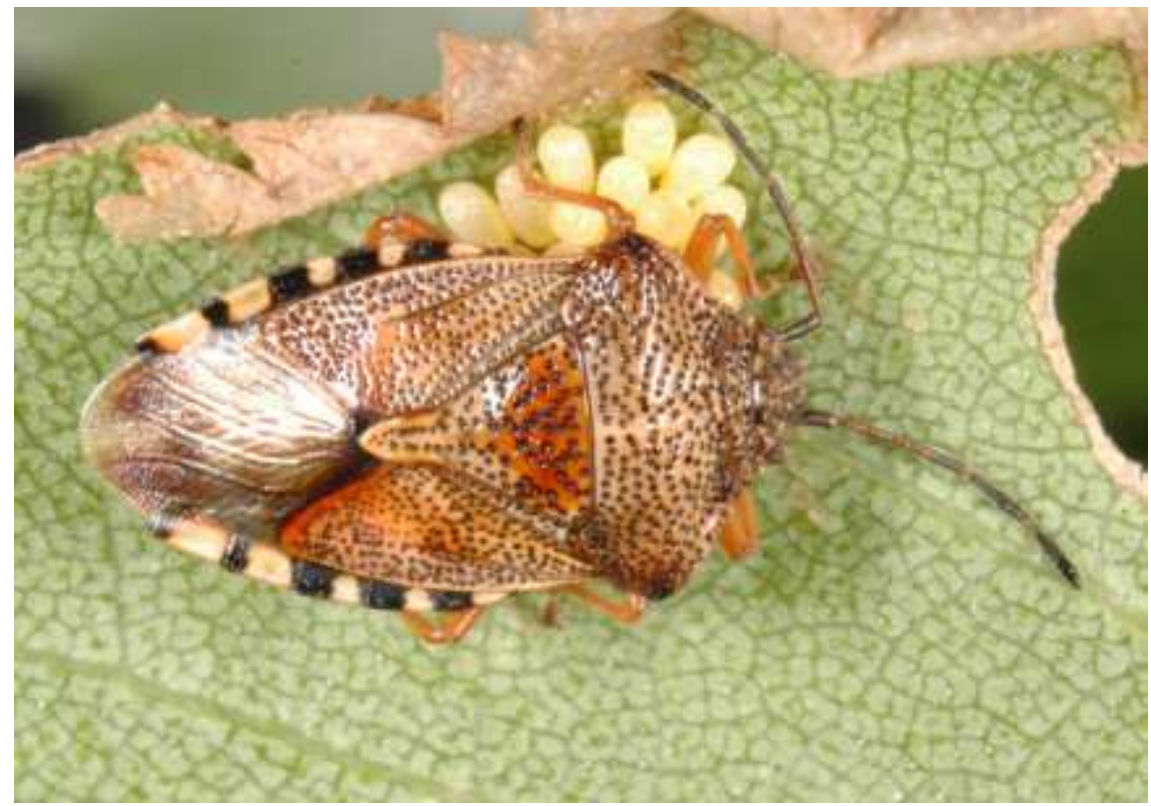

Fig. 3: The Spotted Shield Bug Elasmucha fieberi. The female guarding her eggs. Central Bohemia.

\section{The bug Elasmucha grisea as a didactic model species for maternal care demonstration}

Biology of the bug of the genus Elasmucha was summarized e.g. by Jordan (1958), Melber at al. (1980), experiments with the same species described Mappes and Kaitala (1994), Mappes et al. (1995). Spring sun awakens overwintering adults usually in April-May in Central Europe. Than copulation couples can be found on birch leaves (Fig.4) and later females guarding their clutches.Females protect her eggs and first instar on the place where eggs were laid (Fig.5).They cling tightly on their clutches also in strong windstorms and rains. After the second exuviation, nymphs move from their natal sites on leaves and feed on catkins (Fig.6). 
Envigogika: Charles University E-journal for Environmental Education ISSN 1802-3061

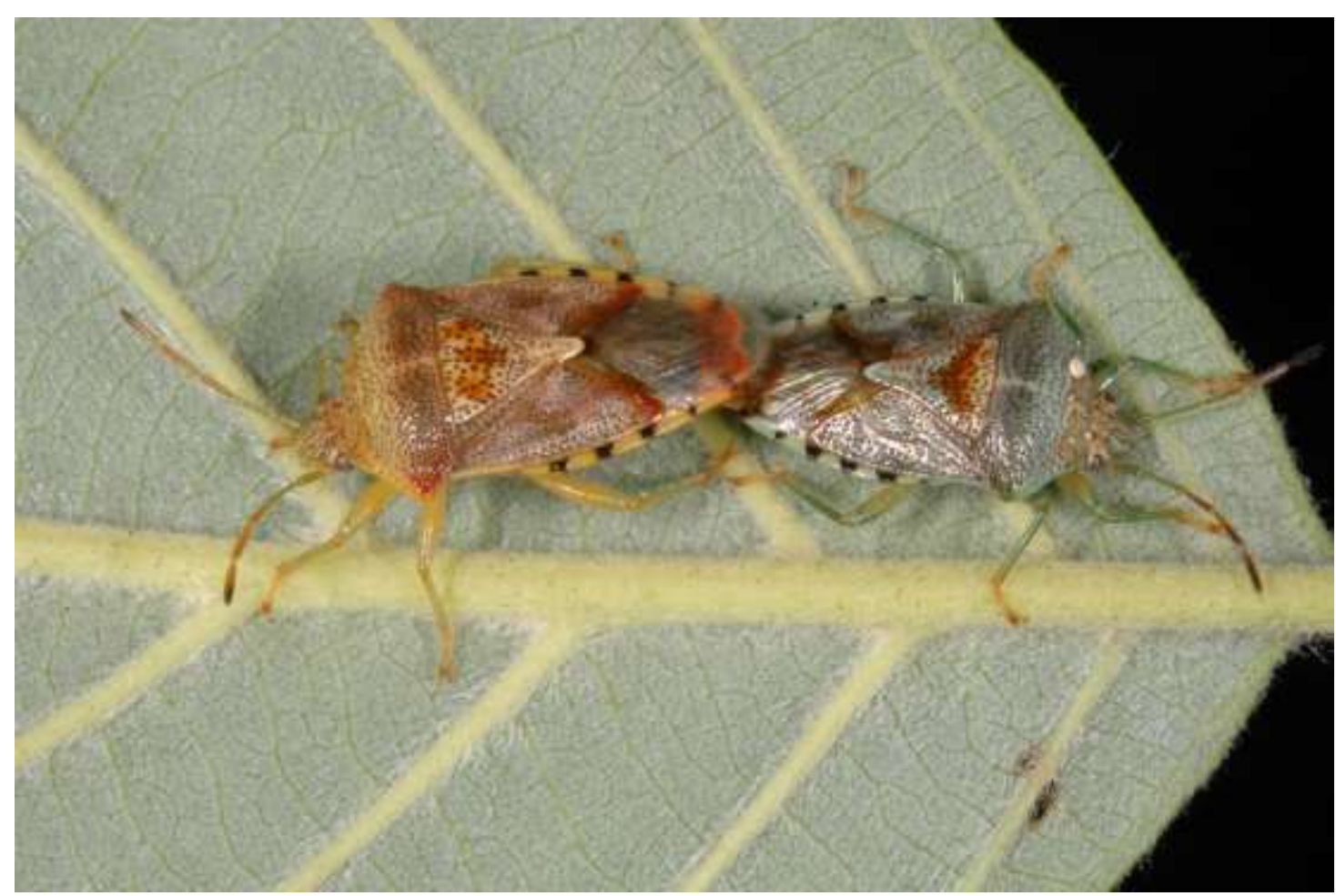

Fig.4: Parent Bug in copulation position, female on the left side. Note: the whitish egg of a parasite Tachinid fly on the pronotum of the male. Central Bohemia.

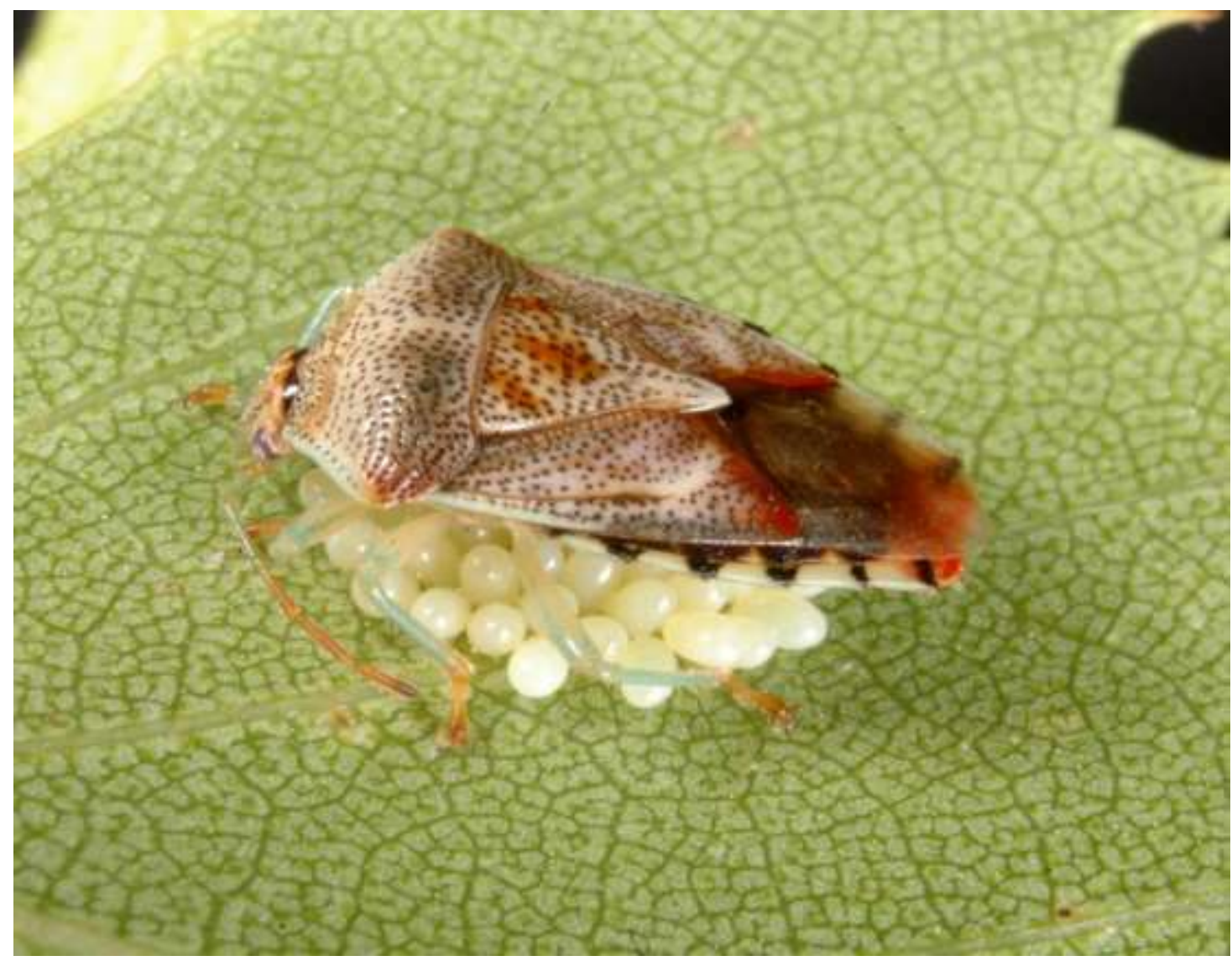

Fig.5: The female of the Parent Bug in the peace guarding her eggs. Her antennae are located along the body. Central Bohemia. 


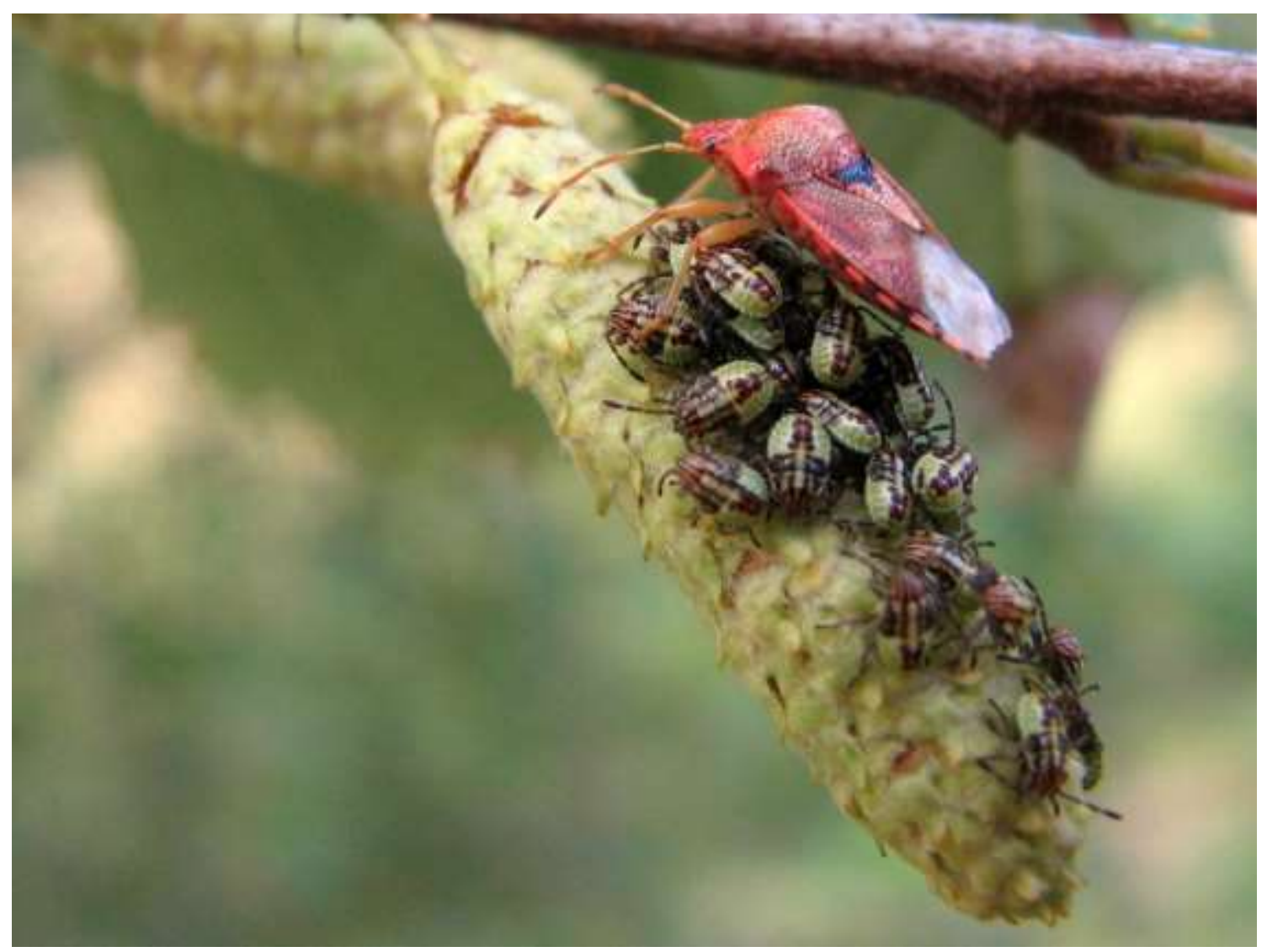

Fig.6: The female of the Parent Bug with nymphs on the green birch catkin, Norway (Photo P. Šrámek).

The mother accompanies her offspring to resting places, following her nymphs and controlling the movement of the whole nymph group. The female is able to correct the movement of nymphs when some of them stray from the correct direction. Moving of nymphs on the branchlets in line formation is probably enabled thanks to trail pheromones, because shield bugs are semiochemically adapted to their life mode (Aldrich, 1988). The larvae are guarded at most until the $3^{\text {rd }}$ stage (instar), than the female stops maternal care but nymphs maintain certain time gathering behaviour (see Fig.7).

The female guards her eggs and later nymphs against invertebrate predators by a cascade of defensive behaviours with different intensity: rapid body jerking, tilting the body toward the source of the disturbance (Fig.8), wing fanning, and finally spraying repugnant secretion toward the disturber (it is known that the females defended larvae at a markedly higher level of intensity than they showed for the eggs, see Hanelová and Vilímová, 2013).

Without maternal protection, predators (usually ants) kill almost all nymphs. Risky habitats (birches with ants) are rejected by discriminating females who select safe birches (Mappes and Kaitala, 1995). When the female dies or is not able to provide an effective shelter for all her nymphs, than nymphs can consequently contact another female with her nymphs and form mixed groups. The second female can adopt other nymphs and guard all members of the mixed group (Roth et al., 2006). 


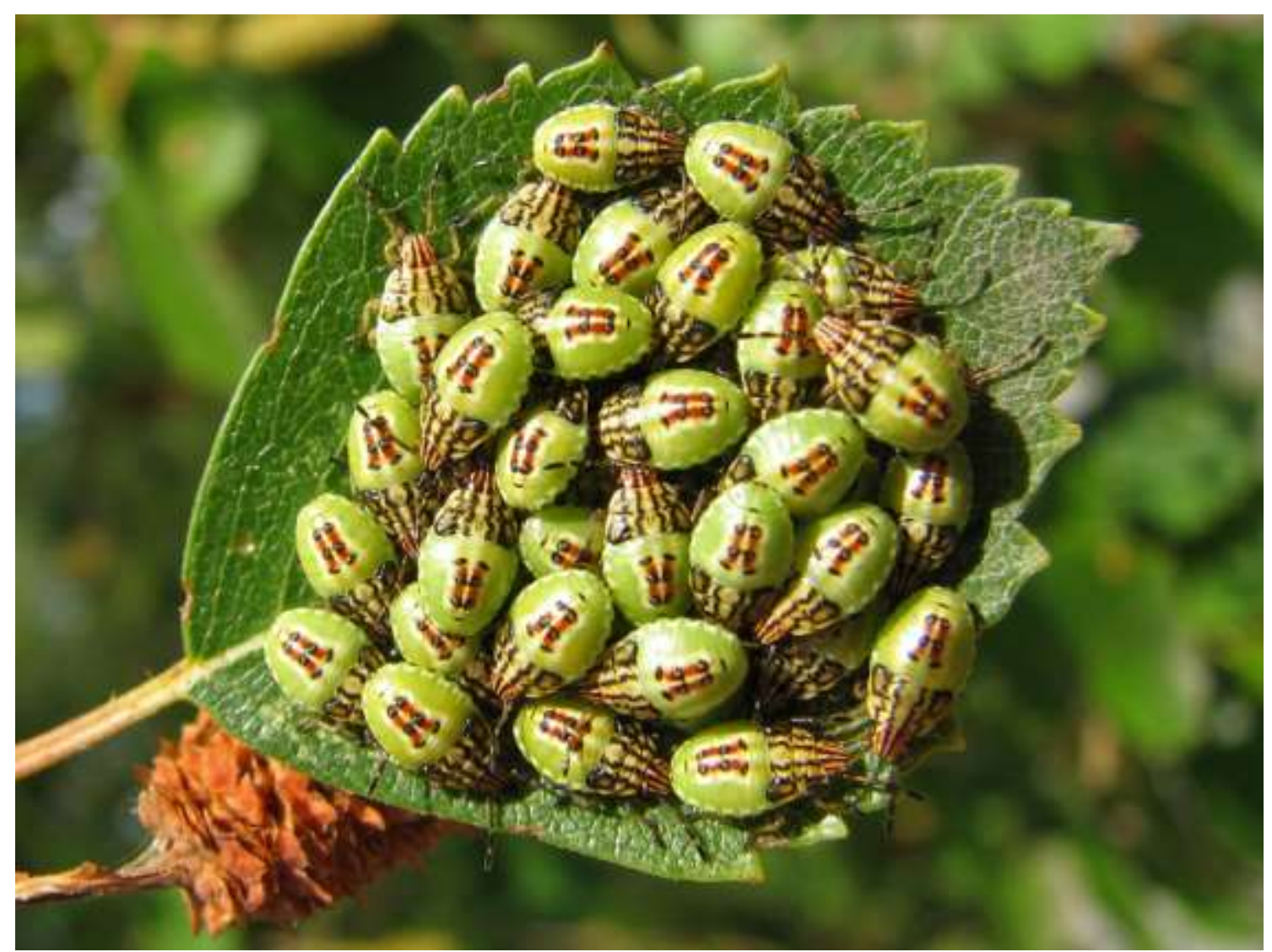

Fig 7: Group of nymphs of the Parent Bug. Sparbu, Norway (Photo P. Šrámek).

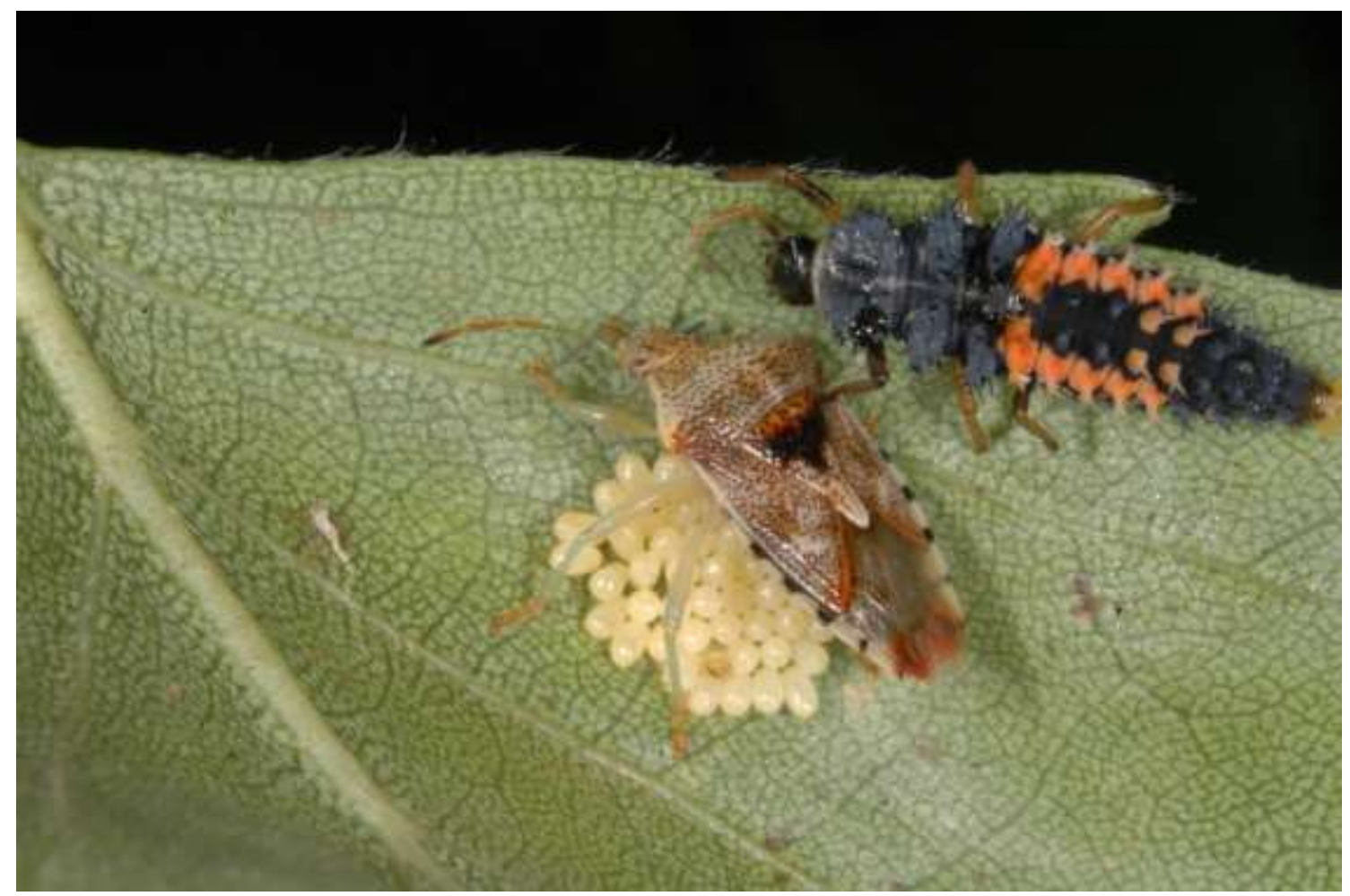

Fig.8: The female of the Parent Bug tilting her body against potential predator (larva of the invasive Multicoloured Asian Lady Beetle Harmonia axyridis). Central Bohemia. This photo was published by Hanel and Hanelová (2011) 
Mappes et al. (1995) reported a new aspect of brood guarding behaviour in the Parent Bug: two or more females oviposit their egg clutches and breed side by side on the same leaf (see Fig.9). This is despite the fact that suitable places for oviposition (birch leaves) are practically unlimited. According to Mappes and Kaitala (1995) this phenomenon is named "joint brood guarding". Mappes et al. (1995) showed that by joint brood guarding both females nearly double their success in defeating predators compared to a single brood guarding female.

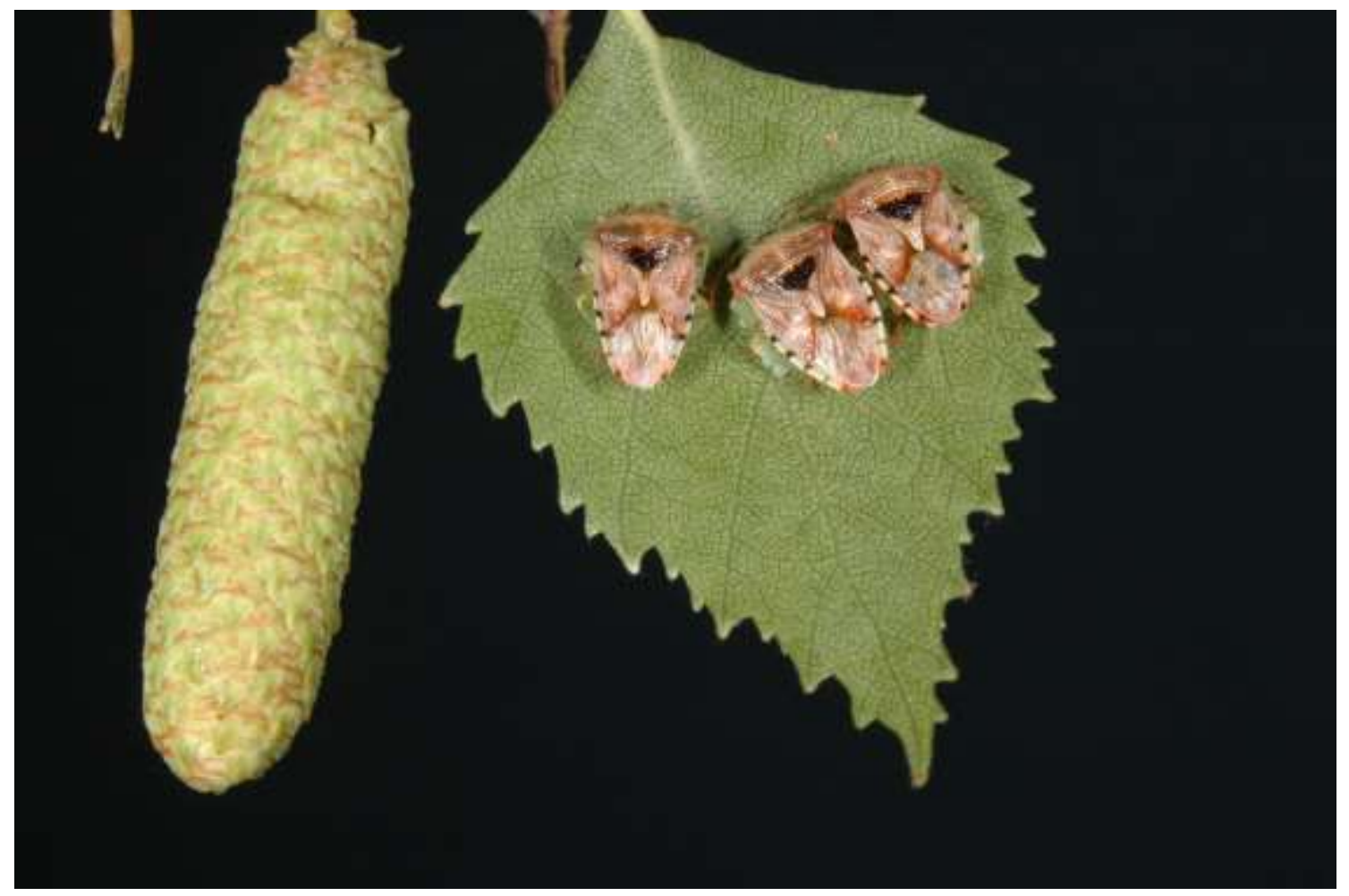

Fig. 9: Three females of Elasmucha grisea with own eggs on the same leaf of the birch tree. They are resting (no response, antennae are located alongside the body). Central Bohemia.

\section{Methodical notes}

In this paper the presented results are based on a study of the Parent Bug Elasmucha grisea in environmental conditions in Central Bohemia (Czech Republic, Europe), the Benešov district near Prague, 400-450 m height above sea level, in 2010-2013. The birch branches (Betula alba) were in selected trees with green catkins carefully checked for egg guarding females from ground level up to 2 meters in height. Both upper and lower surfaces of the leaves were inspected. The distribution pattern of egg guarding females can be investigated and the following questions can be answered: In which \% of examined trees were females guarding their clutches found and how many females were found on branches to 2 meters in height. Leaves of the birch were measured according to Ellis et al. (2009). Midvein length was measured as a distance from the proximal end of the midvein to the distal end. Distribution of sectors on the birch tree for the location analysing the clutch is given in Fig.10. Sometimes a bunch was found in neighbouring sectors. In that case, such a sector was selected where the most of eggs were counted. All photos were taken by authors (unless otherwise stated).

Note: with respect to the occurrence of the bugs of the genus Elasmucha in large territory of European continent, latitudinal effect (earlier breeding in the south than in the north) is manifested. Some publications can be used for determination of Betula trees (e.g. Press, 2001, Russell, 2011). 


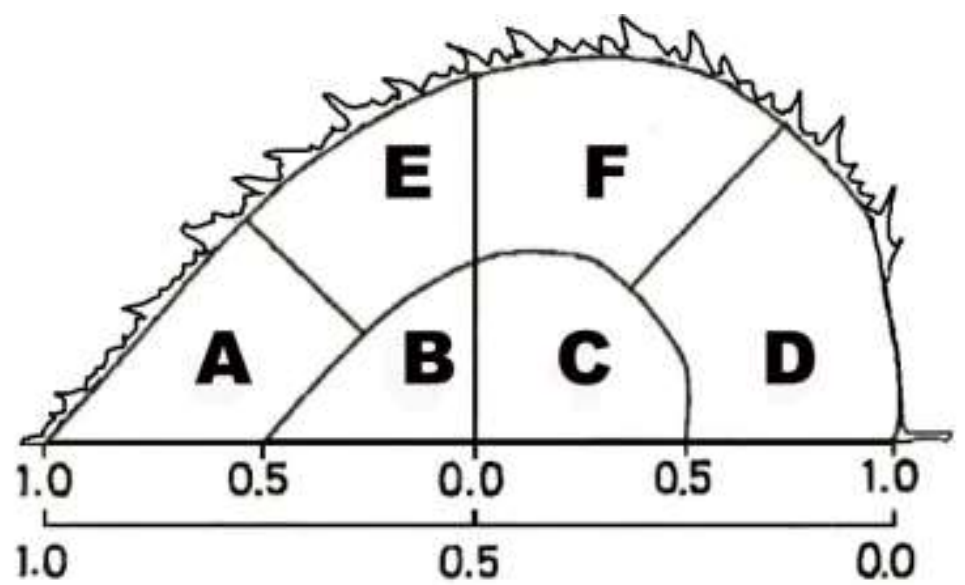

Fig.10: Distribution of six sectors on the birch tree for the clutch location analysis. Orig. drawing by L. Hanel

\section{Explanation of scientific terms}

arthropods - invertebrate animals having the largest phylum in the animal kingdom, including an incredibly diverse group of taxa such as e.g. insects, crustaceans, spiders, scorpions, and centipedes

catkin - usually dense, cylindrical, often drooping cluster of unisexual apetalous flowers

instar - developmental stage of arthropods, such as insects, between each molt (ecdysis), until sexual maturity is reached

invasive species - widespreading non-indigenous species negatively affecting colonized biotopes and native species

nymph - immature form of some invertebrates, particularly insects, which undergoes gradual metamorphosis (hemimetabolism) before reaching its adult stage

pheromones - chemicals capable of acting outside the body of the secreting individual to impact on the behavior of the receiving individual

petiole - the stalk by which a leaf is attached to a stem

phytophagous - feeding on plants

pronotum - the dorsal sclerite of the insect prothorax (anterior segment of the thorax)

\section{Procedure of scientific observations}

Equipment required: magnifying glass, digital camera, mobile microscope (e.g. ProScope Micro Mobile, ProScope Mibile, ProScope HR, HR2), small glass or plastic beaker, entomological pair of tweezers, movable rule, notepad, ballpoint pen, paper with millimetre scale, tree identification field guide. Students can work individually or in groups. 
Envigogika: Charles University E-journal for Environmental Education ISSN 1802-3061

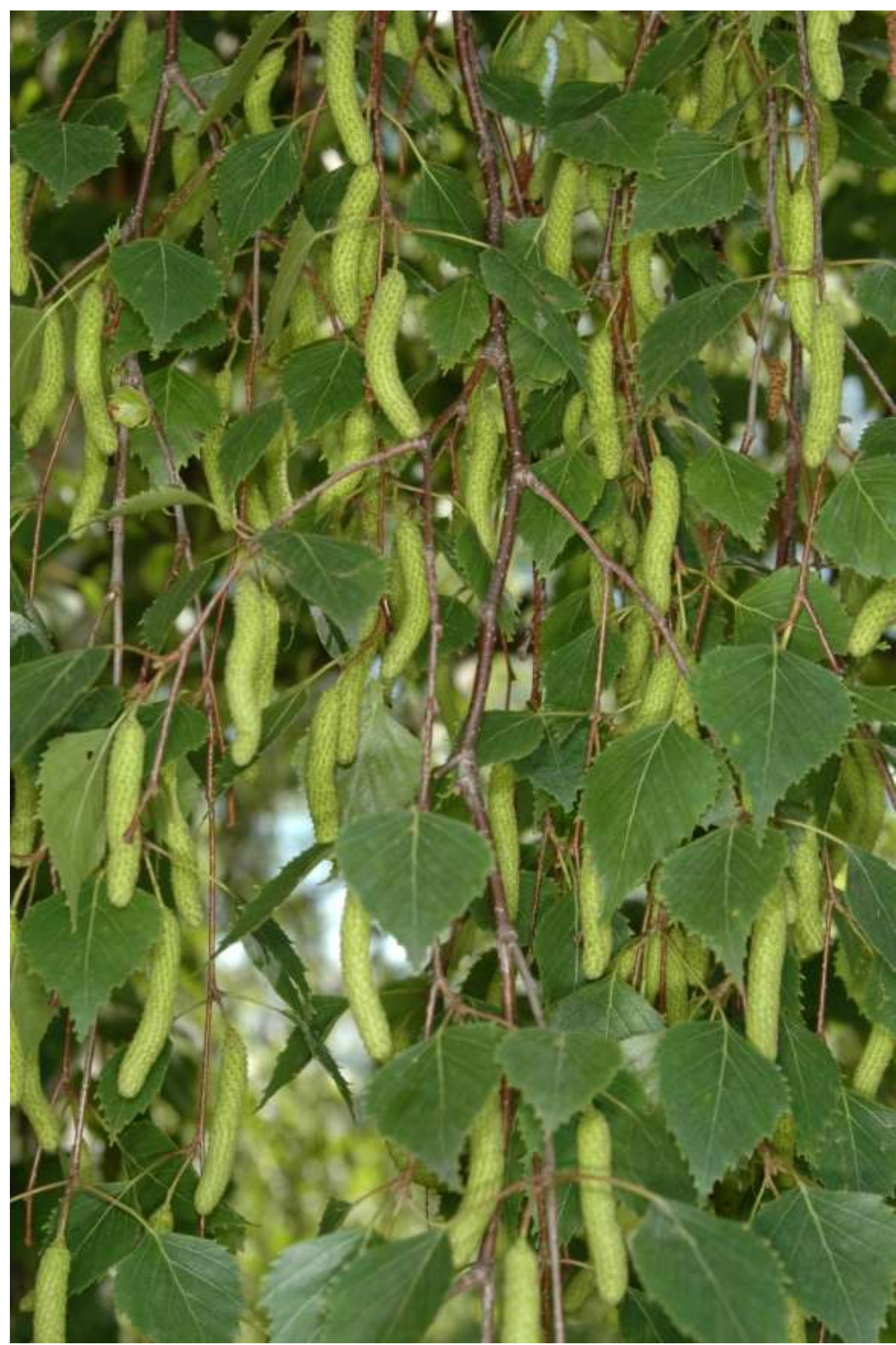

Fig.11: Birch branches with catkins. Central Bohemia. 
1) find birch trees with lower located branches with green catkins (Fig.11). With the determination key or with the help of a teacher specify a birch species

2 ) successively explore birch leaves on low growing branches with green catkins. Carefully check for egg guarding females of Elasmucha from ground level up to 2 meters in height. The upper and lower surface of the leaves must be inspected.

3) measure the length and width of the leaf (with accuracy of $1 \mathrm{~mm}$ )

4) measure the distance between the place of the egg mass and the nearest catkin (measured continually along surface of branchlets including lengths of leaf petiole and catkin petiole)

5) carefully take the female away (by the use of fingers or soft entomological tweezers) and put her into the small flask

6) take a photograph of the leaf with eggs laying on the paper with millimetre scale (see Fig.12), observe the clutch of eggs using magnifying glass or mobile microscope

7) put the female back on the leaf with her eggs (the female will usually accept her clutch after a short time). It is possible to record her behaviour on a digital camera.

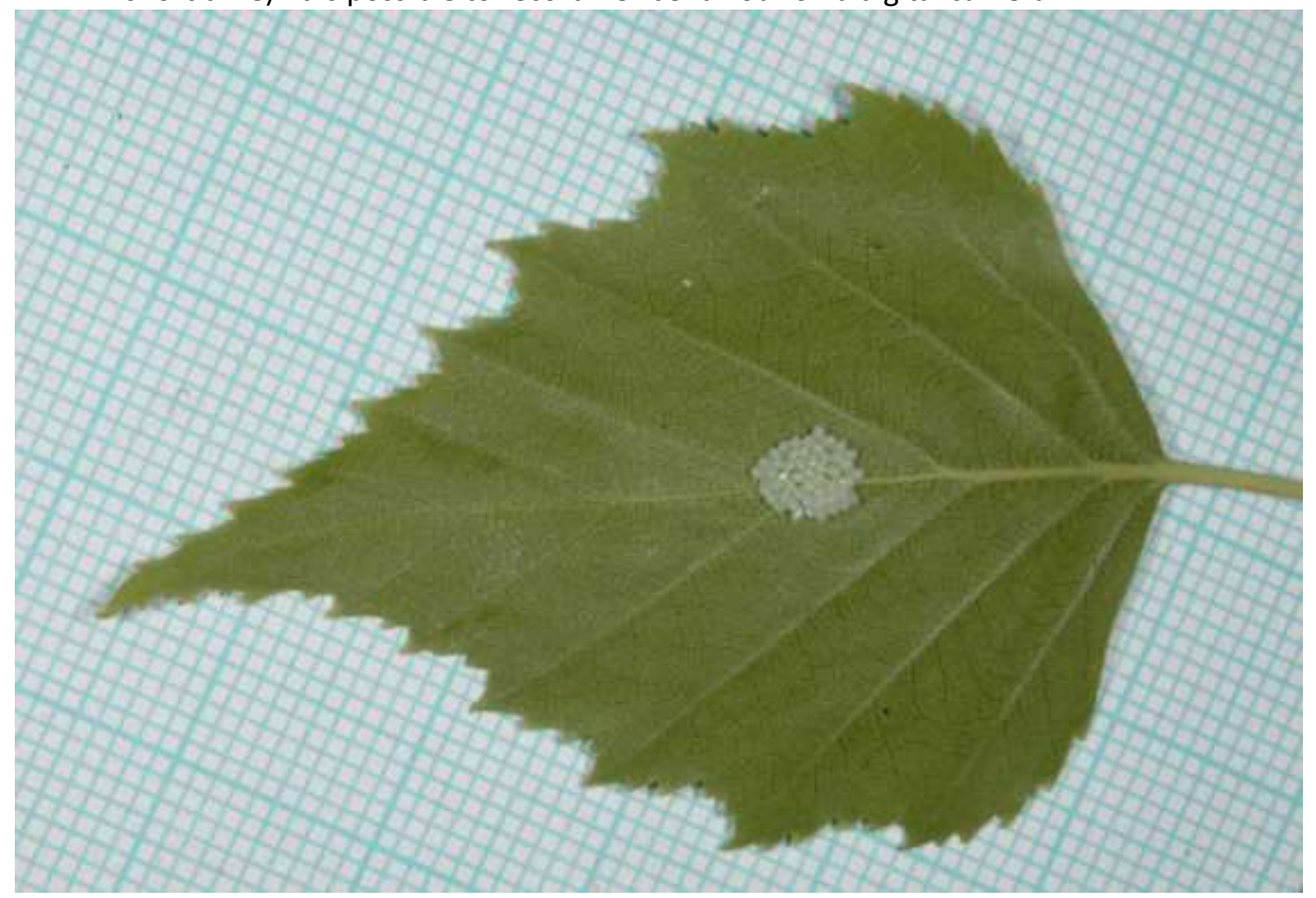

Fig.12: Birch leaf with eggs of the Parent Bug on the paper with millimetre scale.

\section{Processing observations in the school}

8) count up the number of eggs in individual clutches by magnifying digital photos on a PC

9) draw the position of the clutch on the leaf to appropriate sector/sectors in the leaf schema

10) write all gathered data to the table. If a greater amount of data are detected, calculate statistical parameters (see Tab. 1 and following text)

Note: an advantage of this process is returning the female to her clutch in nature. The female can continue guarding her eggs and later nymphs. 
Tab. 1: Summarized results based on own research of the Parent Bug (Elasmucha grisea) on the birch (Betula alba), in Central Bohemia, Czech Republic, 2010-2013. SD - standard deviation, n number of observations

\begin{tabular}{|c|c|c|c|c|c|}
\hline & $\mathbf{n}$ & Average & Minimum & Maximum & SD \\
\hline Number of eggs & 93 & 48.9 & 32 & 60 & 5.297 \\
\hline Length of the leaf (mm) & 93 & 41.0 & 17 & 60 & 9.529 \\
\hline Max. width of the leaf (mm) & 93 & 29.20 & 16 & 48 & 9.195 \\
\hline \begin{tabular}{c} 
Length of the leaf petiole (mm) \\
\hline $\begin{array}{c}\text { Distance to the nearest catkin } \\
(\mathbf{m m})\end{array}$
\end{tabular} 93 & 93 & 69.7 & 15 & 360 & 68.392 \\
\hline
\end{tabular}

Note: in statistics standard deviation shows how much variation or dispersion from the average exists. A low standard deviation indicates that the data points tend to be very close to the mean (e.g. number of eggs), a high value of the standard deviation indicates that the data points are spread out over a large range of values (e.g. distance to the nearest catkin). For calculation of the standard deviation see e.g. Mathematic Learning Centre, Statistics and standard deviation (http://www.cqu.edu.au/ data/assets/pdf file/0009/15966/STSD.pdf ).

\section{Results and discussion}

Results of the authors' own scientific observations of the Parent Bug are summarized in the text below (see also Tab.1). The share of birch trees with guarding females in studied localities was similar to data published by Roth et al. (2006), i.e. about 50\%, the number of females per tree ranged from 0-5 (120 trees were investigated). The number of eggs in clutches varied between 32 and 60, distribution of egg frequency is given in the Graph 1. In most cases egg masses were laid on the ventral side of leaves. Only $25 \%$ of the clutches were placed on the dorsal side of leaves ( $\mathrm{n}$ = 93). Egg masses were concentrated near the base of the leave, often on the midvain. For detailed analysis, area of leaves was divided into six sectors (see Fig.10), most clutches were located in sector " $\mathrm{C}$ " $(55 \%)$, in second place was sector "B" $(22 \%)$, followed by sector " $F$ " $(15 \%)$, sector " $D$ " (5\%) and sector " $E$ " $(3 \%)$; no egg mass was placed in the sector " $A$ " $(n=93)$. The distribution of egg masses is significantly different from a random distribution in leaf sectors $(p<$ 0.001 , Chi-square test, $n=93$ ). The average birch leaf with the clutch had the following parameters: the length $41.0 \mathrm{~mm}$ and the width $29.2 \mathrm{~mm}$, the length of the petiole was $19,9 \mathrm{~mm}$, $(n=93)$. Statistically important dependencies were not found in comparison of the leaf size and the number of eggs (leaf length: correlation coefficient was -0.04 ; leaf width - correlation coefficient was -0.01).

Note: Chi-square is a statistical test commonly used to compare observed data with data we would expect to obtain according to a specific hypothesis. The correlation coefficient is a measure of the strength of the straight-line or linear relationship between two variables. For more details see e.g. Gonick and Smith (1993).

The shortest distance from the place of eggs to the nearest catkin was very variably $15-360$ $\mathrm{mm}$ (69.7 $\mathrm{mm}$ in average). Much higher values were rarely found (maximal value was $270 \mathrm{~cm}$ ), and were eliminated from calculation. These extreme values were caused probably by branches 
being formerly interwoven by the wind and therefore sometimes adjacent small branches with and without catkins were in close contact with each other.

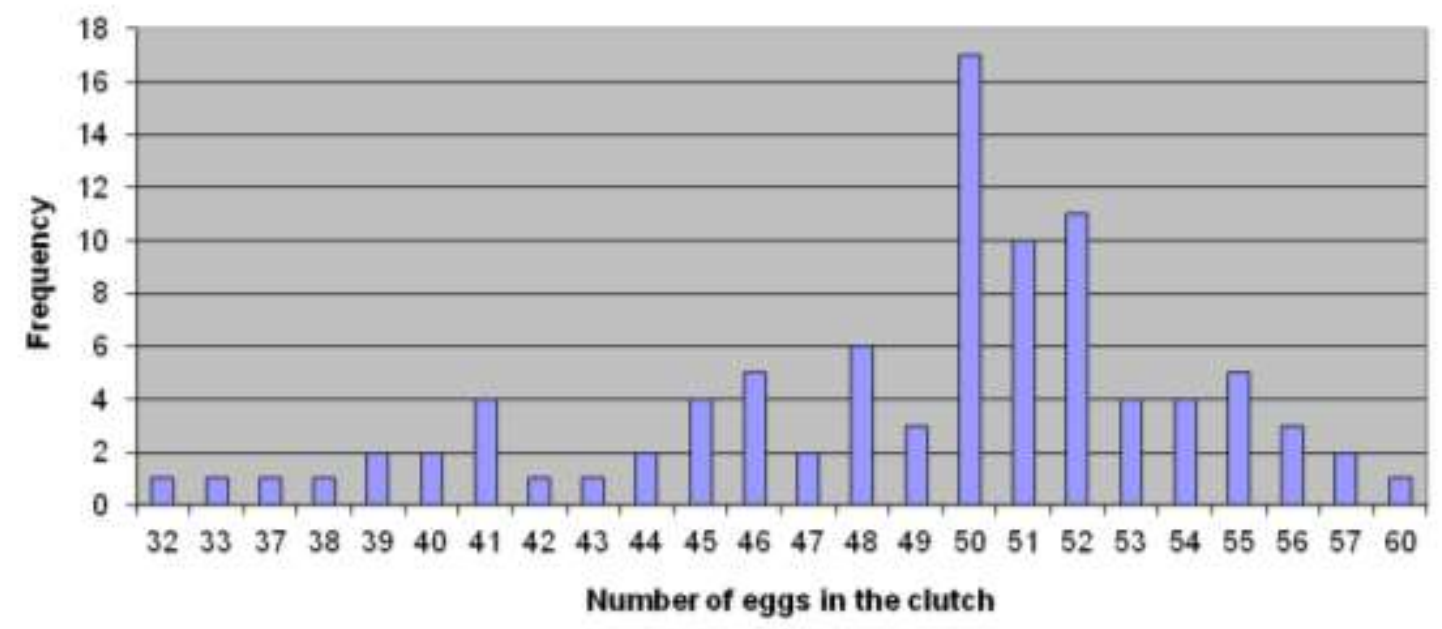

Graph 1: Frequency of number of eggs in clutches of the Parent Bug Elasmucha grisea $(n=93)$, Central Bohemia, period of investigations 2010-2013

Note: according to the authors' own investigations in insectarium, mutual clutch changes between females of the Parental bug and Spotted Shield Bug are possible. It is evident that females cannot distinguish not only their own clutch and other conspecific clutches, but also interspecific eggs (of the above mentioned species). Considering this fact the two-species mixed groups of various stages of nymphs or freshly hatched adults can sometimes be found on birch trees (see Fig.13).

The observation of maternal care in bugs exposes students to all three domains of Bloom's taxonomy.

\section{Affective domain}

It is important to encourage students not only to receive, but also to respond and value their investigation. This is usually not difficult because the students are introduced directly in the hitherto unknown field to observe a remarkable, albeit common, phenomenon of the natural world of which they had no knowledge. They are surprised that individual maternal care occurs among invertebrates, not just among birds and mammals.

\section{Psychomotor domain}

Students can try gentle handling of the branches and leaves of the birch while searching for females with eggs, working with tweezers (carefully removing females from broods), measuring the size of the leaf, recording details of the leaf with the clutch and returning females back to their brood. The affective domain is also involved because students know that research may be conducted without harming the observed animal.

\section{Cognitive domain}

Students can more easily remember and understand the observed phenomenon by using demonstrative observations in the field. Students (and also teachers attending biological seminars) draw on their own knowledge to respond to the observations of maternal care with questions and considerations about whether and where this parental care phenomenon occurs in other animal groups. They recognize that parental care is an important prerequisite for the survival of offspring. Students realize that direct parental care is not seen across all animal species, many of which do not take care of their offspring, but invest their energy into producing a large number of descendants. In addition, students learn to process digital pictures on a PC. They learn about use 
of statistics in getting reliable results which can be used in objective comparison with various observations.

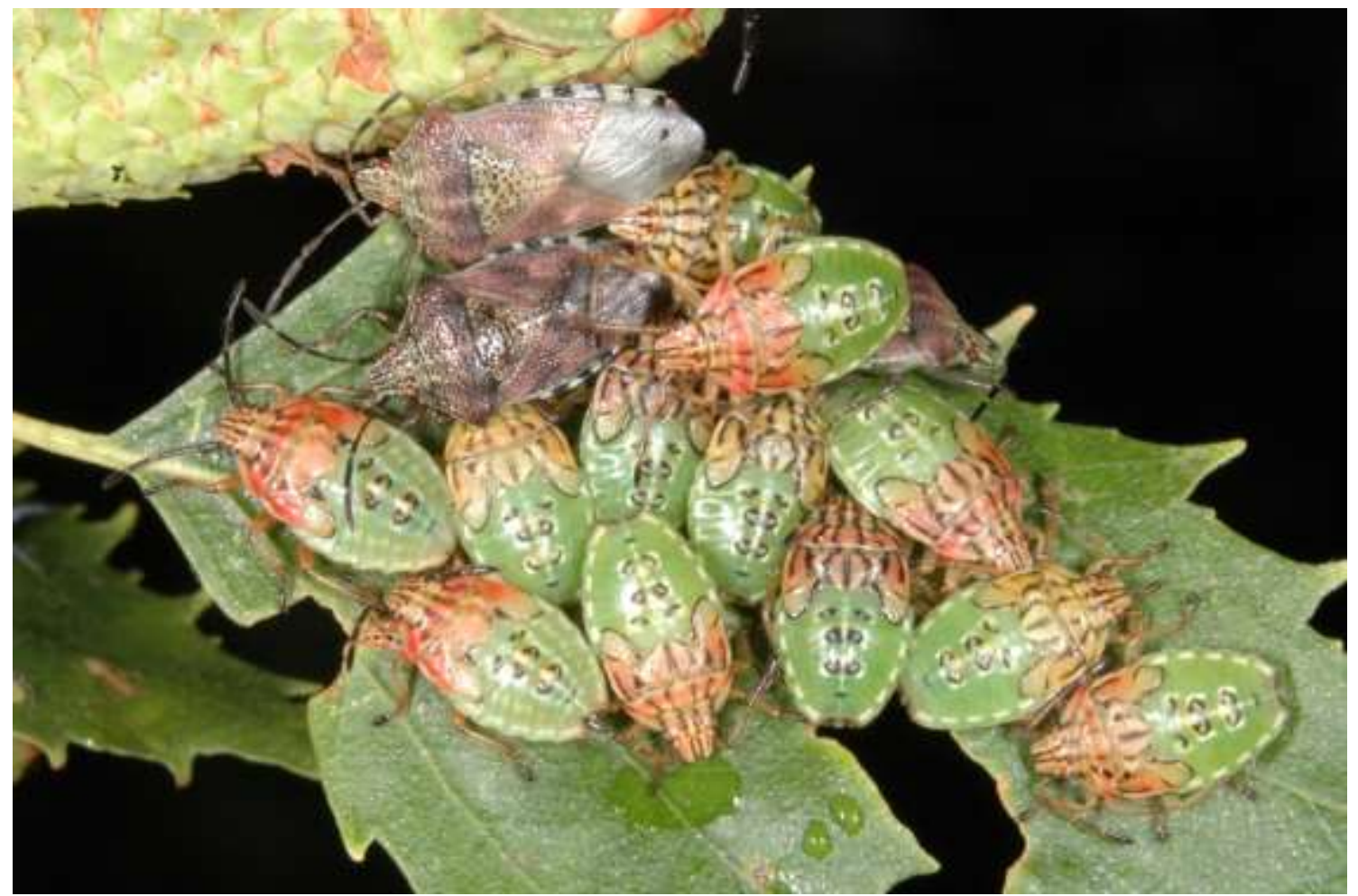

Fig.13: Mixed group of various stages (the $5^{\text {th }}$ instar and freshly hatched adults) of Parent Bug and Spotted Shield Bug. Central Bohemia.

\section{Investigation extensions}

Two genera of acanthosomids with different reproduction strategies can be found on the same birch trees.. Species belonging to the genus Elasmucha (Elasmucha grisea, Elasmucha fieberi) have maternal care. On the other hand there is no known maternal care in the Birch Shield Bug Elasmostethus interstinctus (which also often occupy birch trees, see Fig.14). The female of the latter has green coloured eggs which are laid in several batches on various birch leaves. It is evident that both the described reproduction strategies are currently successful and enable the populations of both species to thrive. Teachers can discuss with students advantages or disadvantages of both strategies with respect to potential changes in environmental conditions. 


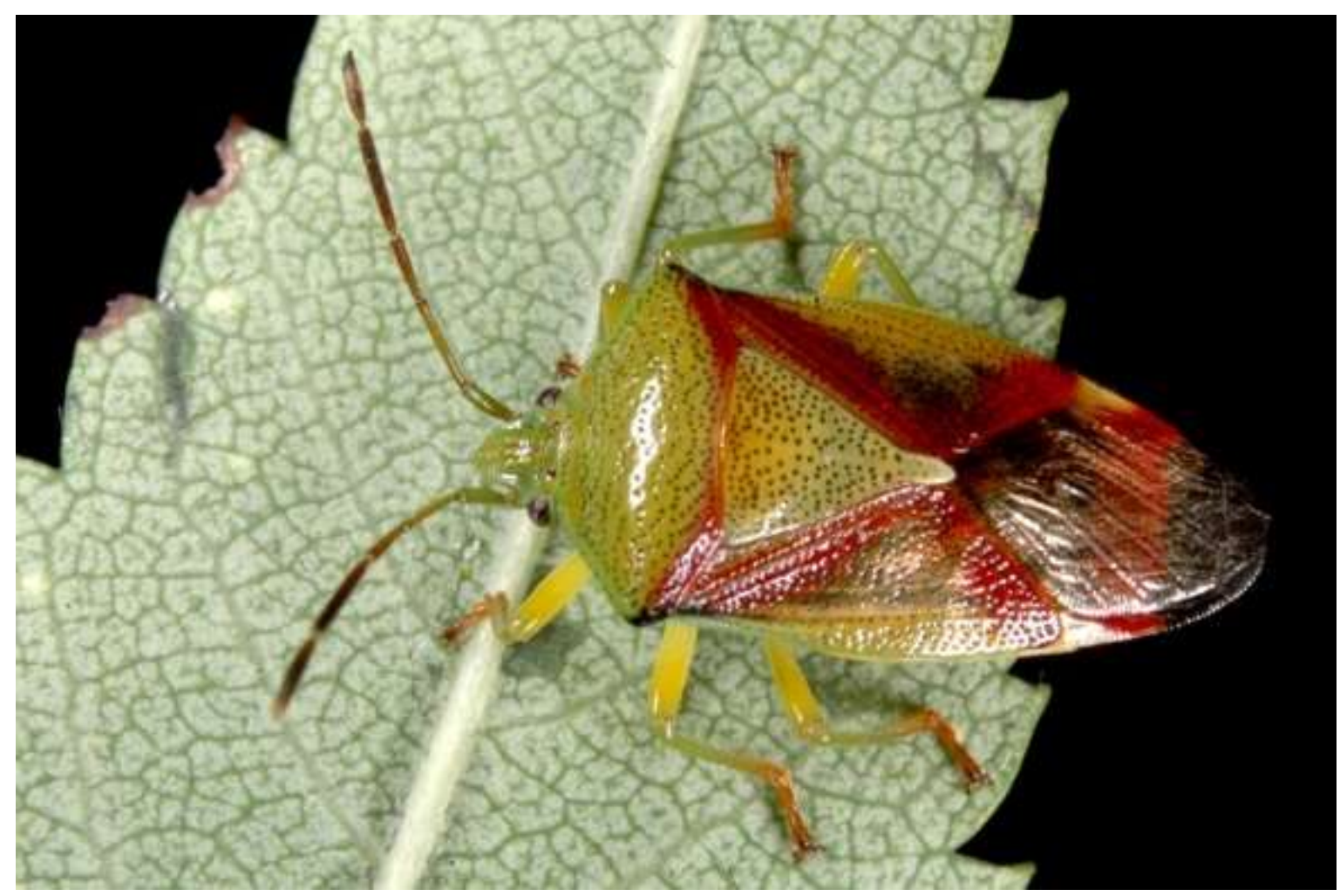

Fig.14: The Birch Shield Bug Elasmostethus interstinctus. Central Bohemia.

\section{Summary}

This paper presents methodological guidance for a research-oriented observation for a class in outdoor biology. This observation can be carried out during field excursions. The Parent Bug (Elasmucha grisea) seems to be a valuable species for the didactic demonstration of maternal care. This species is common on birch trees particularly in Central and North Europe. Females lay several tens of eggs mostly on the ventral side of birch leaves. Then they keep their eggs and later nymphs safe by using their own body to defend against various predators. The females display remarkable behaviour, accompanying their offspring onto catkins (their food source) and then back to the same leaf (resting place). This behaviour is easily observable outside. The outdoor activities of students during their observation were evaluated with respect to the domains distinguished in Bloom's taxonomy, of which all three domains can be developed in the students. A specific procedure for scientific observation is described with respect to data records and their evaluation including a statistical perspective. These results are based on research in the Czech Republic and may be used for comparison with forthcoming research in schools abroad. The results reliably prove the suitability of selected species for student investigations. This paper is relevant particularly for teachers in Central European and Northern European countries, who can carry out field research with their students, summarise and evaluate data. The direct contact and observation of natural objects in their natural environment in terms of visual exemplary teaching has a much deeper and more complex educational effect in accordance with Bloom's taxonomy. The presented research also contributes to students' knowledge of ecology and ethology of insects. The authors hope that the outdoor scientific observation described in this paper could be of use to teachers abroad in the implementation of their teaching practice. 


\section{References}

- Ahmad, J. (2011). Teaching of biological sciences (Intended for Teaching of Life Sciences, Physics, Chemistry and General Science). New Delhi: PHI Learning Private Limited.

- Aldrich, J. (1988). Chemical Ecology of the Heteroptera. Annu. Rev. Entomol, 33(1), 211238. Retrieved from http://www.annualreviews.org/doi/abs/10.1146/annurev.en.33.010188.001235 http://dx.doi.org/10.1146/annurev.en.33.010188.001235

- Ballantyne, R., \& Packer, J. (2002). Nature-based Excursions: School Students' Perceptions of Learning in Natural Environments. International Research in Geographical and Environmental Education, 11(3), 218-236. Retrieved from http://www.tandfonline.com/doi/abs/10.1080/10382040208667488 http://dx.doi.org/10.1080/10382040208667488

- Barker, S., Slingsby, D. R., \& Tilling, S. (2002). Teaching biology outside the clssroom: Is it heading for extinction? A report on outdoor biology teaching in the 14-19 curriculum. Shrewsbury, UK: Field Studies Council.

- Beames, S., \& Ross, H. (2010). Journeys outside the classroom. Journal of Adventure Education \& Outdoor Learning, 10(2), 95-109. Retrieved from http://www.tandfonline.com/doi/abs/10.1080/14729679.2010.505708 http://dx.doi.org/10.1080/14729679.2010.505708

- Bogner, F. X. (1998). The Influence of Short-Term Outdoor Ecology Education on Long-Term Variables of Environmental Perspective. The Journal of Environmental Education, 29(4), 1729. Retrieved from http://www.tandfonline.com/doi/abs/10.1080/00958969809599124 http://dx.doi.org/10.1080/00958969809599124

- Byrd, R. K., Haque, M. T., Tai, L., McLellan, G. K., \& Knight, E. J. (2007). Designing a Children's Water Garden as an Outdoor Learning Lab for Environmental Education. Applied Environmental Education \& Communication, 6(1), 39-47. Retrieved from http://www.tandfonline.com/doi/abs/10.1080/15330150701319859 http://dx.doi.org/10.1080/15330150701319859

- Dale, E. E. (1967). The outdoor laboratory is an aid to teaching biology in the secondary schools. Arkansas Academy of Sciences Proceedings, 21, 100-102.

- Eberbach, C., \& Crowley, K. (2009). From Everyday to Scientific Observation: How Children Learn to Observe the Biologist's World. Review of Educational Research, 79(1), 39-68. Retrieved from http://rer.sagepub.com/cgi/doi/10.3102/0034654308325899 http://dx.doi.org/10.3102/0034654308325899

- Ellis, B., Daly, D. C., Hickey, L. J., Johnson, K. R., Mitchell, J. D., Wilf, P., \& Wing, S. L. (2009). Manual of leaf architecture. Ithaca, New York: Cornell University Press.

- Fägerstam, E., \& Blom, J. (2012). Learning biology and mathematics outddors: effects and attitudes in a Swedish high school context. Journal of Adventure Education \& Outdoor Learning. DOI, 13(1), 10-1080. Retrieved from http://www.tandfonline.com/doi/abs/10.1080/14729679.2011.647432 http://dx.doi.org/10.1080/14729679.2011.647432

- Fido, H., \& Gayford, C. (1982). Field work and the biology teacher: a survey in secondary schools in England and Wales. J. of Biol. Educ, 16(1), 27-34. Retrieved from http://www.tandfonline.com/doi/abs/10.1080/00219266.1982.9654414 http://dx.doi.org/10.1080/00219266.1982.9654414 
- Furst, E. J. (1981). Bloom's Taxonomy of Educational Objectives for the Cognitive Domain: Philosophical and Educational Issues. Review of Educational Research, 51(4), 441-453. Retrieved from http://rer.sagepub.com/cgi/doi/10.3102/00346543051004441 http://dx.doi.org/10.3102/00346543051004441

- Gleason, M. E., \& Schauble, L. (1999). Parents' Assistance of Their Children's Scientific Reasoning. Cognition and Instruction, 17(4), 343-378. Retrieved from http://www.tandfonline.com/doi/abs/10.1207/S1532690XCI1704 1 http://dx.doi.org/10.1207/S1532690XCI1704 1

- Gonick, L., \& Smith, W. (1993). The cartoon guide to statistics. New York: HarperPerennial.

- Hamilton-Ekeke, J. T. (2007). Relative effectiveness of expository and field trip metgods of teaching on pupil's achievement in ecology. International Journal of Science Education, 29(15), 1869-1889. Retrieved from http://www.tandfonline.com/doi/abs/10.1080/09500690601101664 http://dx.doi.org/10.1080/09500690601101664

- Hanel, L., \& Hanelová, J. (2006). Chováme knězovité ploštice (How to keep bugs of the family Acanthosomatidae). Akva tera fórum, 8, 60-65.

- Hanel, L., \& HanelovÁ, J. (2011). Naši knězové rodu Elasmucha a jejich rodičovské chování (Native bugs of the genus Elasmucha and their parental care). Živa, 1, 27-29.

- Hanelová, J., \& Vilímová, J. (2013). Behaviour of the central European Acanthosomatidae (Hemiptera: Heteroptera: Pentatomoidea) during oviposition and parental care. Acta Musei Moraviae, Scientiae biologicae (Brno), 98(2), 433-457.

- Higgins, P. (1996). Outdoor education for sustainability: making connections. Journal of Outdoor Adventure and Experimental Learning, 1(4), 4-11.

- Howarth, S., \& Slingsby, D. (2006). Biology fieldwork in school grounds: a model of good practice in teaching science. School Science Review, 87(320), 99-105.

- Chrouser, W. H. (1975). Outdoor vs. indoor laboratory techniques in teaching biology to prospective elementary teachers. J. Res. Sci. Teach, 12(1), 41-48. Retrieved from http://doi.wiley.com/10.1002/tea.3660120107 http://dx.doi.org/10.1002/tea.3660120107

- Jiskrová, M. (2013). Ploštice čeledi Acanthosomatidae jako modelová skupina k demonstraci různého rozmnožovacího chování. (The bugs of the family Acanthosomatidae as a model group for presentation of various reproductive behaviour. Dissertation). Diplomová práce Katedry biologie a environmentálních studií Pedagogické fakulty UK Praha. .

- Jordan, K. H. (1958). Die Biologie von Elasmucha grisea L.. Beitrage Zur Entomologie, 8, 385-397.

- Kaitala, A., \& Mappes, J. (1992). Luonnon Tutkija. Evolution of Parental Care in Insects, 985, 158-162.

- Kumar, R. (1974). A revision of world Acanthosomatidae (Heteroptera : Pentatomidae): Keys to and descriptions of subfamilies, tribes and genera, with designation of types. Aust. J. Zoo. Supps, 22(34), 1-60. Retrieved from http://www.publish.csiro.au/?paper=AJZS034 http://dx.doi.org/10.1071/AJZS034

- Mappes, J., \& Kaitala, A. (1994). Experiments with Elasmucha grisea L. (Heteroptera: Acanthosomatidae): does a female parent bug lay as many eggs as she can defend?. Behavioral Ecology, 5(3), 314-317. Retrieved from 
http://beheco.oxfordjournals.org/cgi/doi/10.1093/beheco/5.3.314

http://dx.doi.org/10.1093/beheco/5.3.314

- Mappes, J., \& Kaitala, A. (1995). Host-Plant Selection and Predation Risk for Offspring of the Parent Bug. Ecology, 76(8), 2668-2670. Retrieved from http://www.jstor.org/stable/2265839?origin=crossref http://dx.doi.org/10.2307/2265839

- Mappes, J., Kaitala, A., \& Alatalo, R. V. (1995). Joint brood guarding in parent bugs - an experiment on defence against predation. Behav Ecol Sociobiol, 36(5), 343-347. Retrieved from http://link.springer.com/10.1007/BF00167795 http://dx.doi.org/10.1007/BF00167795

- Martin, P. (2010). Outdoor education and the national curriculum in Australia. Australian Journal of Outdoor Education, 14(29), 3-11.

- Matthews, R. W., Flage, and, Lynda R, , \& Matthews, J. R. (1997). INSECTS AS TEACHING TOOLS IN PRIMARY AND SECONDARY EDUCATION. Annu. Rev. Entomol, 42(1), 269-289. Retrieved from http://www.annualreviews.org/doi/abs/10.1146/annurev.ento.42.1.269 http://dx.doi.org/10.1146/annurev.ento.42.1.269

- Melber, A., Hölscher, L., \& Schmidt, G. H. (1980). Further studies on the social behaviour and its ecological significance in Elasmucha grisea L. Hem.-Het.: Acanthosomatidae). Zoologische Anzeiger, 205, 27-38.

- Odhiambo, T. R. (1960). Parental care in bugs and non-social insects. New Scientist, 18, 449-451.

- Openshaw, P. H., \& Whittle, S. J. (1993). Ecological field teaching: how can it be made more effective. Journal of Biological Education, 27(1), 58-66. Retrieved from http://www.tandfonline.com/doi/abs/10.1080/00219266.1993.9655305 http://dx.doi.org/10.1080/00219266.1993.9655305

- Press, B. (2001). Green Guide to Trees of Britain and Europe (Green Guides). : New Holland Publisher Ltd..

- Prokop, P., Tuncer, G., \& Kvasničák, R. (2007). Short-Term Effects of Field Programme on Students' Knowledge and Attitude Toward Biology: a Slovak Experience. J Sci Educ Technol, 16(3), 247-255. Retrieved from http://link.springer.com/10.1007/s10956-007 9044-8 http://dx.doi.org/10.1007/s10956-007-9044-8

- Roth, S., Adaschkiewitz, W., \& Fischer, C. H. (2006) Notes on bionomics of Elasmucha grisea (Linnaeus 1758)(Heteroptera, Acantosomatidae) with special regar to joint broodguarding. In W. Rabitsch (Ed.), Hug the bug. For Love of true Bugs. Festschrift zum 70. Geburtstag von Ernst Heiss (pp. 1153-1167). .

- Rudmann, C. L. (1994). A Review of the Use and Implementation of Science Field Trips. School Science and Mathematics, 94(3), 138-141. Retrieved from http://doi.wiley.com/10.1111/j.1949-8594.1994.tb15640.x http://dx.doi.org/10.1111/j.1949-8594.1994.tb15640.x

- Russell, T. (2011). The Complete Book of Trees of Britain \& Europe: The Ultimate Reference Guide and Identifier to 550 of the Most Spectacular, Best-loved and Unusual Trees. : Southwater.

- Sandell, K., \& Öhman, J. (2010). Educational potentials of encounters with nature: reflections from a Swedish outdoor perspective. Environmental Education Research, 16(1), 113-132. Retrieved from 
http://www.tandfonline.com/doi/abs/10.1080/13504620903504065

http://dx.doi.org/10.1080/13504620903504065

- Sandell, K., \& Öhman, J. (2013). An educational tool for outdoor education and environmental concern. Journal of Adventure Education \& Outdoor Learning, 13(1), 36-55. Retrieved from http://www.tandfonline.com/doi/abs/10.1080/14729679.2012.675146 http://dx.doi.org/10.1080/14729679.2012.675146

- Smith, R. L. (1997) Evolution of parental care in the giant water bugs (Heteroptera: Belostomatidae). In J. Choe \& B. Crespi (Eds.), The evolution of social behaviour in insects and aracxhnids (pp. 116-149). Cambridge: Cambridge University Press.

- Tal, R. (2001). Incorporating field trips as science learning environment enrichment - an interpretative study. Learning Environemnts Research, 4, 25-49.

- Tal, T., \& Morag, O. (2009). Reflective Practice as a Means for Preparing to Teach Outdoors in an Ecological Garden. J Sci Teacher Educ, 20(3), 245-262. Retrieved from http://link.springer.com/10.1007/s10972-009-9131-1 http://dx.doi.org/10.1007/s10972$\underline{009-9131-1}$

- Tallamy, D. W. (1999). Child Care among the Insects. Sci Am, 280(1), 72-77. Retrieved from http://www.nature.com/doifinder/10.1038/scientificamerican0199-72 http://dx.doi.org/10.1038/scientificamerican0199-72

- Vosniadou, S., \& Brewer, W. F. (1992). Mental models of the earth: A study of conceptual change in childhood. Cognitive Psychology, 24(4), 535-585. Retrieved from http://linkinghub.elsevier.com/retrieve/pii/001002859290018W http://dx.doi.org/10.1016/0010-0285(92)90018-W

- Wilson, E. O. (1975). Sociobiology. The new synthesis. Cambridge, Mass: Harvard University Press. 
Lubomír Hanel, Professor of Ecology, Department of Biology and Environmental Studies, Charles University Prague, M. R. Rettigové 4, Praha 1, 116 39, Czech Republic

E-mail: lubomirhanel@seznam.cz

Jana Hanelová MSc., Kladruby 33, 257 62, Czech Republic 